THURSDAY, AUGUST 4, I9ro.

\section{CHRISTIAN TOPOGRAPHY.}

The Christian Topography of Cosmas Indicopleustes. Edited, with Geographical Notes, by E. O. Winstedt. Pp. $\mathrm{x}+376+\mathrm{xiv}$ plates. (Cambridge: University Press, Igog.) Price I2s. $6 d$. net.

THE "Christian Topography" of Kosmas Indiko1 pleustes is a very peculiar work. As a monument of literary style it is precious, for it shows us what terrible rubbish, what wandering and discursive twaddle, people were already writing in the sixth century, when the mental degeneration of the Middle Ages (more properly called the "Dark Ages") had hardly yet set in. As a geographical landmark it is also precious, for the author, twaddlemonger as he was, went to various parts of the East beyond the ken of the ordinary man of the time, and his descriptions of the Somali coast, of Coromandel, and of Ceylon, which he apparently visited himself, in the sixth century, are in the highest degree interesting and valuable. Finally, as a work of unintentional humour, it is beyond price. Of course, the humour of it would not be apparent to all, and it is perhaps irreverent (to the sixth century, which is now somewhat venerable) to direct the reader's attention to this feature of this peculiar work. Yet, since the editor himself indulges in a hearty laugh over the poor old "Christian Topographer," perhaps the reviewer nay be allowed to do so too. At any rate, he sins in the most authoritative company, and if the editor treats his subject (as Mr. Winstedt does) something after the style of Mark Twain and the Yankee at the Court of King Arthur, the reviewer must not be censured if he frivolously suspects the Syndics of the Cambridge University Press of having produced a humorous book.

For, really, Mr. Winstedt's introduction to Kosmas is-pitched in rather too humorous a tone. Such a quotation as "they didn't know everything down in Judee" (p. I5) is a fault of taste, and one can imagine the bewilderment of a French or German scholar at such an unintelligible sentence as "when he can momentarily get free from the obsession of his King Charles' head-the 'great cosmographer Moses ",! (p. 9). Mr. Winstedt presumably intended this book to be of use to international science, but if so, why has he so ill-advisedly interlarded his otherwise most learned and interesting introduction with comic relief only comprehensible to Englishmen or Americans who know their Dickens and Mark Twain?

Kosmas is funny enough of himself without any editorial attempt to make him funnier by means of jarring modern jests, and Mr. Winstedt may be permitted to enjoy, as he does without spoiling things, the good man's explanation of why the Creation took six days when the Deity could ex hypothesi have done it at a single coup if He had liked; the reason is that the angels were such weak-minded creatures that if $\mathrm{He}$ had created everything all at once they would not have understood it at all, so $\mathrm{He}$ tools six days about it for their sake, in order that they might NO. 2 I 27 , VOL. 84] fully comprehend how it was done. This, of course, in all seriousness and devoutness. But it shows how weak-minded people were themselves already becoming as early as the sixth century. To a civilised man of three centuries before, the idea would have seemed as comic as it does to us.

The stupidity of the Dark Ages is already in full blast in the mind of Kosmas the Indian-farer.

"What scholar (as the editor quotes from Marion Crawford's 'With the Immortals ') has not laughed at the idea of Kosmas, the Alexandrian, that the sun retired behind a mountain to spend the night? And that the earth, the ocean, and the fabulous mountain were all included and enclosed in a luminous oblong box of the exact shape of the tabernacle of Moses?"

He undoubtedly had Moses "on the brain" (though we demur to the use of the expression "King Charles' head" in a scientific work); for him Moses was the "great cosmographer." Religious preconceptions and misunderstood texts were jumbled up in his mind with fragments of the old knowledge and the results of his own travel experiences to produce this extraordinary farrago which he called "Christian Topography," a title which, as the editor says, is excellent, "as it cannot possibly convey any particular meaning to anybody." Photius calls the book a commentary on the Octateuch. It

" might as well be called that as anything else, since Cosmas quotes and comments on a considerable portion of the Octateuch. That, however, was not the main object of his work. His intention was to refute the theory that the earth was round, and to prove that Moses' tabernacle in the wilderness was a model of the universe."

This was his theory, which he illustrated from his own travels, and it is the account of the travels that forms the serious interest of the book to us nowadays as giving a most interesting account of the East in the sixth century, and invaluable information as to the geographical ideas of the time. Kosmas observed the habits and customs of the peoples he visited, and noted the animals and plants of their countries, with care. He also drew pictures of the latter, in which undoubtedly he gave some freedom to his imagination. These pictures, copied and re-copied, have come down to us in the later MSS. of his book, no doubt, somewhat changed en route, but still characteristic. Several of them are reproduced by Mr. Winstedt. The picture of a man picking coco-nuts (plate xiv) is especially interesting. Pictures of his weird conception of the universe are, of course, given (plate vi), and the diagram by which he sought to throw contempt upon the horrid theory of Antipodes. The way in which the men of the Middle Ages resolutely set themselves to abjure and ban the theory of spherical worlds, which their civilised ancestors had already promulgated, is curious and characteristic. Kosmas quotes Scripture at length against the wicked pagans who believe in a round world, and his further quotation from Athanasius's "Festal Letters" in support of the current. Christian view has chanced to be the means of preserving to us almost all that survives of the Greek text of that work.

Another thing of value that has been preserved in 
the "Christian Topography" is the text of two important historical inscriptions which he copied at Adulis, the modern Zulla. One of these was set up by officers of Ptolemy Euergetes, and commemorates that great king's conquests in the East; the other was added by a local king of the Axumite dynasty, probably in the second century A.D., to chronicle his conquests in Abyssinia. Historians have to be grateful to the "Christian Topographer" for the preservation of these two documents, and also for the valuable information which he gives us here and there as to the history of his own time. Thus he copied the Adulite inscriptions at the request of Asbas, the Axumite grovernor, who had been ordered to send copies of them to his master, King Ellatzbaas, who was just then about to set out on his famous expedition to Arabia against Dhu Nuwâs, king of Himyar, which was so brilliantly successful. This was about the year 525 A.D. He gives us also invaluable information as to the great spread of Christianity in the East by the sixth century, especially in Persia and India.

The book, therefore, was fully worthy of an adequate Enylish edition, and, having made our caveat as to certain blemishes in dealing with the comic side of the subject, we can say that the editor has done his work well, especially, no doubt, upon the textual side.

\section{TROPHOBLAST AND THE EARLY DEVELOP. MENT OF MAMMALS.}

Die Säugetierontogenese in ihrer Bedeutung für die Phylogenie der Wirbeltiere. By Prof. A. A. W. Hubrecht. Pp. v+247. (Jena: Gustav Fischer, 1909.) Price 7 marks.

T $T$ is now twenty years since Prof. Hubrecht pub1 lished, in the pages of the Quarterly Journal of Microscopical Science, his classic researches on the trophoblast and allantoic placenta of the hedgehog, Erinaceus europaeus. This work, along with the investigations of. Eduard van Beneden and M. Duval, may be said to have revolutionised our knowledge of the placental phenomena in the mammalia. By it new light was thrown on the egg-cleavage, the socalled gastrulation, and, especially, on the mode of origin and the nature of the "fotal membranes," the chorion (trophoblast), amnion, and allantoic placenta. For the Dutch investigator this was the starting-point of a long period of painstaking researches into the placental conditions of diverse mammals, and of these the present work is an author's translation of the English version, published (November, 1908) in the journal containing his earlier results.

So long ago as 1894 , under the title "Spolia nemoris," an appetising account was given of the wonderful array of material of mammalian development, which, in the Dutch East Indies, had either been collected personally or obtained and sent to Utrecht by others. We do not recall any similar journey in quest of embryological material which has been attended by such remarkable success in enlisting, and retaining, the altruistic help of so many different collectors. Other embryologists remember, to their sorrow, the failure of attempts to increase their collections by the aid of others and amateurs. NO. 2 I 27, VOL. 84]
This vast material, much of it of rare and interesting species of mammals, has served as the basis of Prof. Hubrecht's researches, and with great generosity he has placed it at the service of other investigators in the Zoological Institute of Utrecht. The limits of space assigned to this notice allow only a general reference to the work before us.

What is trophoblast? The word and the thing may be described as the main theme of the work, even though it treats also of the egg-cleavage, germinal layers, allantoic placenta, and the descent of mammals. According to Hubrecht, trophoblast is a specialised portion of the outer layer, the epiblast, of the embryo, and he identifies it more particularly as equivalent to that portion of this layer which in amphibians, for example, forms the outer or covering layer. This latter, admittedly, takes no share in the formation of embryonic structures, and it, and trophoblast also, is regarded by Hubrecht as larval and transitory in character. On the other hand, another mammalian embryologist, Mr. Richard Assheton, has recently again urged the view that trophoblast is in reality a derivative of the inner layer or hypoblast. Apart from other considerations, this identification is, in our opinion, negatived by the circumstance that nowhere in the animal kingdom is the hypoblast known to be formed, as is the trophoblast, as a product of the first cleavages of the egg. Prof. Hubrecht's own recognition of its embryonic epiblastic nature (that it is really a part of "the embryo") seems to be disproved by his own researches on Tupaja. Of the eight products of the egg-cleavage here, seven are destined to become trophoblast, while out of the eighth the whole of the embryo, including presumably its epiblast, is unfolded. If the two foregoing objections be valid, the explanation of the nature of trophoblast must be sought elsewhere, for as yet no one has had the temerity to suggest the remaining alternative, the third germinal layer or mesoblast, as its source of origin.

The truth is, as so often happens in embryology, far too little account has been taken of physiological considerations. The trophoblast arises early in development, and never takes part in the formation of embryonic organs, but instead thereof it eats and erodes its way into the uterine wall, and in doing this it destroys the epithelial lining and much besides. If this happens to be in a tubal (oviducal) gestation, the erosion is finally through the oviduct, with sudden and often fatal hæmorrhage into the abdominal cavity. A mass of cells, trophoblast, which can do this, and in the absence of a normal embryo may become the most deadly form of cancer, chorio-epithelioma, can have no nutritive import for the embryo, as its name falsely implies, nor by any stretch of the imagination can it be assigned to either epiblast or hypoblast, for there is nothing in embryology to indicate that embrvonic epiblast or hypoblast possesses this property of eroding and destroying maternal tissues. It is not intended as a reproach to the author, or in depreciation of the immense value of his published researches to science, when this lack of information on the physiological and biochemical side is insisted upon. In fine, like so much in embryology, 